
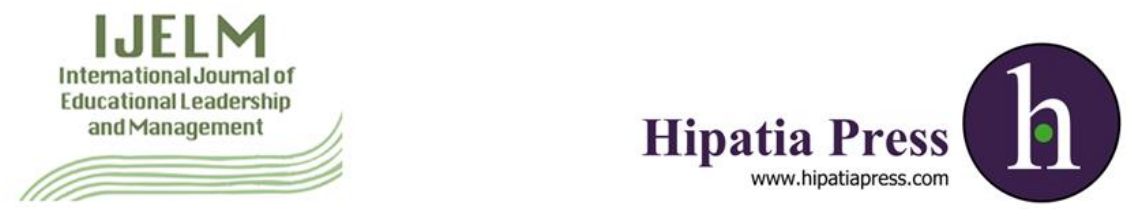

Instructions for authors, subscriptions and further details:

http://ijelm.hipatiapress.com

\title{
Complexity Leadership Theory: A Perspective for State-Owned Enterprises in Ghana
}

Francis Donkor \& Dongmei Zhou ${ }^{1}$

1) University of Electronic Science and Tecnology of China. China

Date of publication: July $16^{\text {th }}, 2019$

Edition period: July 2018 - July 2019

To cite this article: Donkor, F. \& Zhou, D. (2019). Complexity Leadership Theory: A Perspective for State-Owned Enterprises in Ghana. International Journal of Educational Leadership and Management, 7(2), 139-170. DOI:10.17583/ijelm.2019.3647

To link this article: http://dx.doi.org/10.17583/ijelm.2019.3647

\section{PLEASE SCROLL DOWN FOR ARTICLE}

The terms and conditions of use are related to the Open Journal System and to Creative Commons Attribution License (CCAL). 


\section{Complexity Leadership Theory:}

\section{A Perspective for State-Owned Enterprises in Ghana}

Francis Donkor

University of Electronic Science

and Technology of China
Dongmei Zhou

University of Electronic Science and

Technology of China

\section{Abstract}

This article explores the need to change the bureaucratic leadership structure which has bedeviled state-owned enterprises for many decades and how they compete in the 21 st-century business environment where there are uncertainty and chaos. The SOEs suppose provide employment, meet social and political needs, and operate in the sectors of the economy that are of strategic importance to the state. Therefore, SOEs are critical to economic development in emerging economies. The pace of change confronting organizations today has added complexity to the organizational landscape and now calls for more flexible and adaptive leadership. Adaptive leaders can work more effectively in the unstable global business environment and are also able to adopt a proactive approach in order to keep abreast of the increasing stakeholder pressures in the enterprises. However, inadequate applicability of traditional leadership models has indicated the need to develop new leadership models to solve the complex organizational challenges. Hence complexity leadership approach seeks to combine these dynamics to the bureaucratic hierarchies in order to explain the way informal organizational dynamics function correctly and also to describe how these valuable adaptive functions can be promoted to better the operations of SOEs in Ghana

Keywords: Bureaucratic leadership; Complexity Leadership Theory; State-Owned Enterprises; Complex Adaptive System; Ghana 


\section{Teoría del Liderazgo de Complejidad: Una Perspectiva para las Empresas Estatales en Ghana}

Francis Donkor

University of Electronic Science

and Technology of China
Dongmei Zhou

University of Electronic Science and

Technology of China

\section{Resumen}

Este artículo explora la necesidad de cambiar la estructura de liderazgo burocrático que ha acosado a las empresas durante décadas y la competición en el entorno empresarial de incertidumbre y caótico del S.XXI. Las SOE proporcionan empleo, satisfacen necesidades sociales y políticas, y operan en sectores de la economía que son de importancia estratégica para el Estado. Las empresas son fundamentales para el desarrollo económico de las economías emergentes. El ritmo del cambio que enfrentan las organizaciones en la actualidad ha agregado complejidad al panorama organizacional y exige un liderazgo más adaptable. Los líderes flexibles pueden trabajar más eficazmente en el inestable entorno empresarial global y también pueden adoptar un enfoque proactivo para mantenerse al tanto de las crecientes presiones en las empresas. Sin embargo, la aplicabilidad inadecuada de los modelos de liderazgo tradicionales ha indicado la necesidad de desarrollar nuevos modelos de liderazgo para resolver los complejos desafíos organizativos. Por lo tanto, el enfoque de liderazgo de complejidad busca combinar estas dinámicas con las jerarquías burocráticas para explicar la forma en que funcionan correctamente las dinámicas organizacionales informales y para describir cómo estas funciones de adaptación pueden promoverse para mejorar las operaciones de las empresas estatales en Ghana.

Palabras clave: Liderazgo burocrático; Teoría del liderazgo de complejidad; Empresas de propiedad estatal; Sistema adaptativo complejo; Ghana.

2019 HipatiaPress

ISSN: 2014-9018

DOI: $10.17583 /$ ijelm.2019.3647
Hipatia Press www.hipatiapress.com

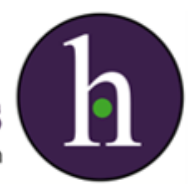


I

$\mathrm{n}$ all human endeavors, leadership continues to exhibit influence on individuals and organizations in ways of doing things or achieving their objectives. The bureaucratic leadership style focuses on the behaviors and traits of individual leaders as appropriate means to determine leadership efficacy. In some manufacturing and state-owned enterprises, these theories of traditional bureaucratic leadership approach and decision-making strategies persist even though technology and innovation suppose to have taken the more significant part of making organizational objectives achievable through the use of advanced business strategies. This supposed to describe the best way of leading a 21 st-century business organization. The development of modern theories has adjusted the thinking of leadership for both practitioners and scholars to shift their attention to the contemporary approach of leading. Entities are seen as a complex system that can be adopted for effective leadership. This suggests that an organization that deals with organisms are a complex system that at all times, will affect leadership structures as well as the duties of the leaders. Research on leadership and organizations points out that organizations are operating in an increasingly complex and dynamic environment (Marion \& Uhl-Bien, 2011).

The instability of the global business environment has added complexity to the organizational landscape. Corporate leaders have found themselves in a turbulent business environment that challenges them to respond quickly and positively to the environment. Literature posits that managers must rapidly shift away from the ancient management techniques and adopt contemporary leadership styles, which according to Bass (1999) multifactor leadership theory and full range leadership theory would be either laissez-faire, transactional or transformational. The leadership style within an organization is a significant determinant of the attainment of goals and objectives, as well as the day-to-day operations of the corporation.

For organizational change and its adaptive circumstances to be effective, Abbas and Asgar (2010), think that there should be useful and competence in one's leadership style. This leader should be able to perceive what is desirable and deal with it tactfully. Hijazi, Kasim, \& Daud, (2017), also believe that managers have what it takes to determine the future direction of the entity 
independently. They further postulate that they can design, build, and control the future of their organizations also. Even though there is no evidence that people understand the role of a leader to be all-inclusive. Drucker (2012), has it that organizations of today are engulfed with a complex and competitive system of environment known as the threshold of chaos mostly led by globalization and technology revolution. To this extent, enterprises supposed to adopt strategies that are a knowledge-based, innovative and creative thinking that enhance quicker decision making and can afford to change the traditional bureaucratic structure to a new and modern style of leadership that resonates with new system development and are flexible when it comes to organizational decision making. This is only how an organization will survive in this chaotic environment of today (Byrne \& Callaghan, 2013; Adams \& Stewart, 2015).

For a modern-day organization to survive the technology, innovation, and global competition in this unpredictable, volatile, and environmental chaos, the managers should think of complexity leadership. This study, therefore, aims to set the center stage for the state-owned enterprises (SOEs) in Ghana that engage in traditional bureaucratic leadership style where the formal structure is seen as the rigid rule for setting goals to be achieved. In this regard, the complexity leadership framework in the ecosystem organism of the SOEs will be understood. The article will explore the knowledge-based conditions, which are most current for the development of creativity and solution to organizational adaptive capacity determinants to be able to achieve goals or objectives set by the state.

Primarily, complexity leadership theory will be well understood through the exploration of the required qualities of leadership by the SOEs. This will be weighed against the restrictions of the traditional bureaucratic model that has been practiced over the years. In this regard, the complexity leadership theory model that distinguishes itself from the traditional model and the role they play in the knowledge-based era where technology and innovation is the way forward will be clarified. 


\section{Methodology}

A systematic review approach was adopted to find research on state-owned enterprise and the leadership approach that best fits it was conducted from the existing literature. This involved extensive search in the extant literature through the replicable procedure (Tranfield et al., 2003). The main aim of this literature review was to identify and discuss the study trend and find the gap in the leadership and SOEs management in a general public sector organization. A systematic literature review is a broader way of soliciting literature in a structured procedure (Jesson et al., 2011).

The researchers used the keyword search on all the available peer-reviewed articles that relate to the public sector in general and SOEs in particular that has been published over the years now. The databases like Google Scholar, ScienceDirect, Business Source Complete, Digital Commons, ERIC were the point of contacts. Another aspect of the search was to look at the title and abstract to filter the relevant papers that relate to bureaucratic leadership, SOEs, and complexity leadership theory. Again, other key journals were found in ResearchGate to augment what we have. We received 124 articles but further sifted it to 70 and added some materials from literature related books. The information gathered were used below to address the underresearched area in the SOEs leadership, and it must be emphasized here that all the SRL stages were followed to arrive at this stage.

\section{State-Owned Enterprises in Ghana}

The history of SOEs dates back to the 1960s and 1970s when the governments of Asia, Africa, and Latin America developed these enterprises to address economic and social needs (Jain, Gupta \& Yadav, 2014; Tanlamai \& Juta, 2011). The mandate of SOEs includes social goals, such as job creation and providing essential services (Tsamenyi, Onumah \& TettehKumah, 2010; Pratuckchai, \& Patanapongse, 2012). These organizations contribute to the socio-economic life in emerging markets (Thomas, 2012). As SOEs perform market-based activities, such as manufacturing, they assume a profit-oriented structure (Pratuckchai \& Patanapongse, 2012). 
SOEs also support infrastructure services in a community such as transportation, broadcasting, hospitals, schools, roads, housing, and social intervention programs (Pratuckchai \& Patanapongse, 2012). Thus, SOEs are critical to economic activity in emerging market countries. The creation of SOEs was meant to provide employment, meet social and political needs, and operate in the sectors of the economy that were of strategic importance to the state (Pratuckchai \& Patanapongse, 2012). Thus, the motives for the creation of SOEs included social goals beyond financial profit (Pratuckchai \& Patanapongse, 2012). SOEs in Ghana is primarily in the manufacturing industries, extractive- mining, quarrying, and utilities - industrial, domestic power, and water supply (Odainkey \& Simpson, 2012). Ghana's SOEs contribute to approximately $30 \%$ of total industrial output in the country (Odainkey \& Simpson, 2012). Unpredicted challenges such as globalization negatively impacted on the profitability of SOEs (Chen, Wang, Huang \& Spencer-Rodgers, 2012). In the 1980s, Ghana could boast of over 300 SOEs but has now been reduced to 86 , due to several factors of which the leadership is a major one. This comprises 46 wholly state-owned and 40 joint ventures. In 2016, 18 of, these SOEs wholly owned by the state incurred a total loss of 791 million cedis (\$ 200 Million). The failure of SOEs continue to burden government which has equity position. To address these challenges, governments adopted two separate strategies including privatization and the development of structural reforms (Odainkey \& Simpson, 2012). In our view, the latter strategy of structural reforms to take care of the traditional bureaucratic leadership which gives the administrative leaders more authority to suppress informal (adaptive) be dealt with for proper functioning of these SOEs. This is so because the role of the SOEs are still relevant in today's global business environment where uncertainty and chaos affect predictability of the market. The publics still need our SOEs to function well to provide heterogeneous products and services and open employment opportunities for the teaming youth. 


\section{Bureaucratic Leadership Style in SOEs}

According to Weber (1946), the bureaucratic structure is characterized by well-defined roles and responsibilities, a hierarchical structure, coordinated by rules, functionally departmentalized, and impersonal system and respect for merits. Jaques (1989) posits that bureaucracy is structurally organized into production functions (e.g., line or lower level management), organizational functions (e.g., middle-level management), and executive functions (e.g., toplevel management, strategic). The finding enhances this assertion by the study on optimal hierarchical structures of organizations that can commit to their organizational structure but not long term wages (Shin, \& Strausz, 2013). In this modern knowledge-based era, the management of our SOEs is organized around the traditional bureaucratic leadership model where formal structure which depicts impersonal relationships exists. The structure is such that communication is solely formal and impersonal, which adopts a selfprotective position towards proper behavior, which in most circumstances, affects organizational performance due to its rigidity. These bureaucratic leaders tell subordinates what they should do on the grounds of the policy of the organization, procedural, and guidelines laid down from the onset. In bureaucratic leadership, rules are absolute. Bureaucracy in the organization again is the arrangement designed as to how day to day activities are carried out. This is represented by officials who are tasked to perform different functions provided according to their status and roles. The leader works by job description and his job as a manager is more like a judge who does not entertain any act of excuses in the discharge of duties (Weber, 1946). A bureaucratic leader does allow any free room for his subordinates to operate. Therefore their freedom is curtailed (Javadin, 2007).

The bureaucratic characteristics are sometimes in conflict with some of the theories of leadership. Wright (2008) posit that, to be stable and predictive and to have equity in the bureaucratic environment should result in relying on a mechanism to be able to limit the discretion of individuals and enhance uniformity in how members understand and respond to the organizational situation and task. With this inflexibility in bureaucratic organizations, leadership is facing obstacles in its implications. Wriston (1980) suggests 
three basic principles, which include hierarchy, formalization, and centralization. According to Millett (1967) "hierarchy generally refers to a system of organization in an enterprise whereby there are variously defined levels of authority and responsibility" (p 423). Armandi \& Jr (1985) also mentioned that "Formalization looks at the degree to which tasks are standardized. This implies written rules to be followed and stipulates negative sanctions in cases of rule violations" (p 266). Hsu, Marsh \& Mannari (1983) defined centralization as "the distribution of authority within the focal organization" ( $p$ 976). According to them, centralization in the bureaucratic context concerns authority and decision making. In other words, the smaller the group that makes the decision, the more centralized the organization is going to be.

Mullins (1999) further asserts that formal and informal leadership in our enterprises have a relationship that affects the way they do their daily activities. In every business entity, there is a formal bureaucratic leadership structure that functions as departments and makes sure the objectives are achieved. There also exists in the informal enterprise relationship established by groups which in most cases not recognized by the formal leadership structure that serve the interest of its members either positively or negatively. In addition to the formal hierarchical structure in the organization, the informal groups also help individual members in their job performance and the entire organization. The formal structure, which represents the bureaucracy in state-owned enterprises gives direction as to how members in the organization function officially to achieve organizational objective. People within the groups use their social domination to impose their wills on other members. Leadership is supposed to ensure that both formal and informal members within the enterprise work effectively to produce the desired results through resource allocation mobilized by the enterprise to carry out strategic plan. Leaders ought to use the structure to establish the relationship between the individuals and groups to motivate workers effectively and efficiently helps achieve organizational output (Rogers, 2017). 
Bureaucracy, according to Abdullah et al., (2013) is a management system that was purposeful to looks at the affairs of the state and how it relates to the people within the society. The bureaucratic system here looks at standard processes and procedures, bookkeeping, and how decisions should be made with an organization. That is checks and balances. The extent of bureaucracy within the enterprise or the organization determines its activities and attributes of such an organization. The members in the bureaucratic systems are professionals who are well-trained line and staff officers who are on full-time employment and who perform administrative functions and tasks. It must be stated here that these people are not elected to take up positions. The structure of bureaucracy looks at how the staff is arranged to function to deliver organizational objectives. The chart of a bureaucratic structure is in the form of a pyramid with a vertical line of communication from the top executives to the bottom rank and file.

Within the organization also exists informal organization which consists of the relationship between individuals and groups based on their day-to-day interactions, emotions, personal attitudes, like and dislike, prejudices, cultural and religious affiliations. This informal structure is not sanctioned by the formal authority but can arise across formal structures due to personal and social relations of the people within the organization. Members in this informal structure do not work in their official capacities but as persons who share hopes and aspirations, joy, sorrow, and fear together. Informal organizations do not have laid down rigid rules and authority as the formal bureaucratic structure has, but it has leadership. Again, it has unwritten norms and behavior which govern the members. This determines methods of correction and how to punish those who fall foul to the norms of the group. The informal organization gives life to the formal structure to function well to achieve organizational objectives. For the formal organization to perform better, it ought to support from the informal organization. For an organization to be orderly and efficient members in the formal and informal structure should have cordiality in their operations so that success could be harmoniously achieved. The moment there is hostility between these two structures, the enterprise becomes deficient in achieving objectives. 
Leadership results in the attainment of organizational goals (van Vugt, 2006). Chan \& Chan (2005) posits that leadership has a relationship between the leader and his followers. There is a degree of leadership capabilities in every individual; the tendencies may vary among individuals. However, formal bureaucratic leaders most at times neglect the informal leaders (Schreiber \& Carley, 2005), though they both exist in the same environment seeking the success of the same enterprise (Loughead, Hardy \& Eys, 2006; Painter-Morland, 2008). Informal leaders are found to be very significant contributors to organizational leadership, but formal leaders most often fail to leverage their powers (Pescosolido, 2001; Yukl \& Becker, 2006).

For efficiency and effectiveness in the organization to be realized, the formal bureaucratic organization may need the backing of the innovativeness of the informal organization. Unfortunately, the relationship between the two structures has always been complicated and exciting because of obvious reasons. Rogers (2017) concludes that persistent association and interaction between the formal and informal organizational members will yield the emergence of informal structure. This informal structure will consist of group relations and creates mutual ties that will bring aid and assistance to augment the innovations being sought for. Both formal and informal group members play various essential roles in the organization for it to achieve its stated objectives as stipulated by the bureaucratic structures. The members in these groups must be either persuaded, threatened, or coerced to take part or participate in the functioning of the organization. However, in all situations, subordinates fully participate in organizational performance when there is an expectation. In other words, when the members in the group are expecting to benefit from the system or the outcome of their participation like promotion, prestige, or high pay from their actions.

These expectations serve as motivation for the members to fully participate in organizational success. This suggests that informal members must be identified with the decision making in order to help the organization achieve its goals. It is a fact that members in the organization feel satisfied if they are seen to be part of a more critical decision-making group. This enhances or motivates them to work their hearts out. 
Every member of the SOEs has his or her motivation that makes him or her play the role to help achieve organizational goals. Every business organization will only achieve success if there is proper coordination among members internally and externally. This is because people working in the organization have different reason or motive of joining the group, and their contribution to the organizational goals must be seen to be identified and mentioned. Business enterprises cannot function well without their informal members.

The contributions of all the informal members, coupled with the formal members, put together to achieve equilibrium. To do these members on both sides should be induced to work well to achieve success. This should happen at all level of the organization.

In this case, the outlook of the activities within the organization will either increase or reduce at each level of the enterprise. Uhl-Bien and Marion (2009) suggest that functionally departmental barriers state the authority and responsibilities that are interdependent are just descriptive and unrealistic and whose effects will hinder the attainment of organizational goals.

\section{Complexity Leadership in SOEs}

Leadership styles in traditional bureaucratic structure have been to get subordinates to go by the structures laid down to achieve organizational goals. Traditional leaders do this by the use of motivation, and the flow of information is from top to bottom (Bass, 1985). The leaders get their plans implemented through interactive relationships with the individuals. In the bureaucratic structure, the leaders get subordinates to follow the laid down rules to prevent subordinates from resistance to change, preventing objection to their decisions. All these implementations and rigid rules are to achieve organizational objectives. Interventions by subordinates are out of the question in most circumstances. The leader is seen to have all the strategies to influence the system, and all he does is the right thing. 
Frederick Taylor in 1926, as cited by Bass (2002), suggested that there is a possibility of social forces subverting processing procedure. The relation here is described as a struggle between rationality and irrational forces who do not want organizational goals to be achieved (Selznick, 1948). Barnard (1938) posits that formal (administrative) leaders are performing as leaders because the informal structure accepts them as such. Lewin (1952) thought informal behavior could be exploited to create change in the organization. Recent researchers and scholars have suggested that these two structures in organizations are conflictive with elites taken the roles of administrative to suppress workers in the informal structure (Jermier, 1998). Lewin (1952) again, did not see it as 'conflictive but rather as something that can be nurtured and enabled.' It should be seen as a valuable force that brings about effective change in the organization. To be able to achieve useful organizational objective, formal and informal organization ought to be fostered but not managed (Uhl-Bien, Marion \& McKelvey, 2007). Uhl-Bien \& Marion, (2009), moves beyond traditional bureaucratic structure and adopt complexity thinking to analyze the informal (adaptive) structure critically. They further suggest that entanglement of formal and informal bureaucratic structure unify the two and continued to see informal dynamic structure as a valuable resource in any organization where complexity leadership theory happens to foster these resources. To effectively address these dynamics and integrate formal and informal structures, three primary functions of complexity leadership in the traditional bureaucratic organization has been adopted. The three models according to Uhl-Bien \& Marion (2009); Waldman \& Bowden (2016); Bowden \& Smits (2015); Baltaci \& Balc1 (2017) includes -administrative leadership, adaptive leadership, and enabling leadership. These functions described as entanglement.

This age of business environment creates some kinds of problems for enterprises and their leaders (Schneider, 2002; Baltaci \& Balc1, 2017). In this post-industrial period, the achievement of state-owned enterprises depends on its human capital and organizational members thinking capabilities as compared to physical abilities (Fidan \& Oztürk, 2015; McKelvey, 2001). In an economy like Ghana, that wants to be industrialized in this 21 st century, how to coordinate physical assets, subordinates created to become a 
challenging task. This is mainly due to the problem of manufacturing optimization and the flow of products (Schneider, 2002; Alcácer, Cantwell \& Piscitello, 2016). Within this new system of economy, the problem is creating an environment that reduces cost and increases productivity while accumulating knowledge. The objective is to develop, cultivate, and produce products that cannot be easily reproduced by competitors within the growing chaotic and competitive environment (Nonaka \& Nishiguchi, 2001).

Chesbrough (2006) reiterated that 'intellectual knowledge accumulation is settled through the transformation of knowledge' (page). This has been a challenge of various organizations through distributed intelligence over the cellular network rather than limited production of information on particular members in the enterprise who are seen to be the few brains at the top capable of doing the organization works (Miles, Snow, Matthews \& Miles, 1999). In all these, the attention should be on how quickly and adaptable the enterprise could be rather than who controls who which is the best for production sectors (Jones, 2000). Organizations of this modern era should have their attention on resonance with new conditions, new thinking, and learning alongside productivity and organizational control (Marion, 1999). This is because the traditional bureaucratic structure lacks the concept of formal leadership, which restricts the applicability of these modern times (Uhl-Bien, Marion \& McKelvey, 2007). The shift predominantly by these theories tries to avoid uncertainty by looking at the aspect of organizational functions and structures.

However, the tendency towards structural issues for the quest of stability in the unpredictable and constantly growing competitive business world of today may affect organizational growth (Northouse, 2015). The problem is to offer alternatives to bureaucratic structure that has been used in SOEs and how best to use these alternative theories in practical terms. In the same vein, arguments like organizational structure, workforce planning, and technology to define uncertainty can encourage organizational objectives and how it is to be achieved (Burpo, 2006). New leadership theory is needed to replace the bureaucratic leadership theory as it has a very slight chance of meeting the modern-day leadership strategy to manage competitive and chaotic business 
environment today. Complexity leadership is premised on the fact that management should be simplified. This provides managers with resonance skills to manage uncertainty that may arise instead of over control by the top managers and suppression in the course of its activities (Waldman \& Bowen, 2016).

Past studies have revealed that the dynamics make achieving stated objectives insufficient and informal group dynamics are not adhered to (Baltaci and Balc1, 2017). Edmonstone (2016) observed that the ability to resonate with new conditions that are focused on new forms of authority, distributed authorities, and the dynamics of social networks in interaction with informal groups is not satisfactory.

For this to be successful, organizations must increase the adaptivity in their ecosystem around the organizational level rather than justifying their traditional structure (Ashby, 2013; Boisot \& McKelvey, 2010). They proposed in simple terms that 'chaotic level of organizations in the same environment should be the same in order for complexity to overcome complexity.' In this case, the system will function effectively. This required that complexity will help the system capacity (human, capital, and technical) to search for a solution to the problems and introduce new ways of doing things in the production sector of the enterprise. That is the complexity system will improve creativity, adaptability, and organizational learning.

The traditional bureaucratic organization has devised a simplified solution in the pursuit of adaptation. Such an organization has concluded on strategies that define fixed boundaries and make communication simplified (Cilliers, 2005). Cilliers further suggested that these approaches will lead to static structure because there should not be fixed perimeters that create restrictions on the function of organizational members. To be able to meet these needs, this new era of leadership requires a paradigm shift in thinking from individualism and control to view the entire enterprise as an ecosystem that allows innovation to continue to acquire complexly adaptive knowledge. 
Image 1

Traditional Leadership.

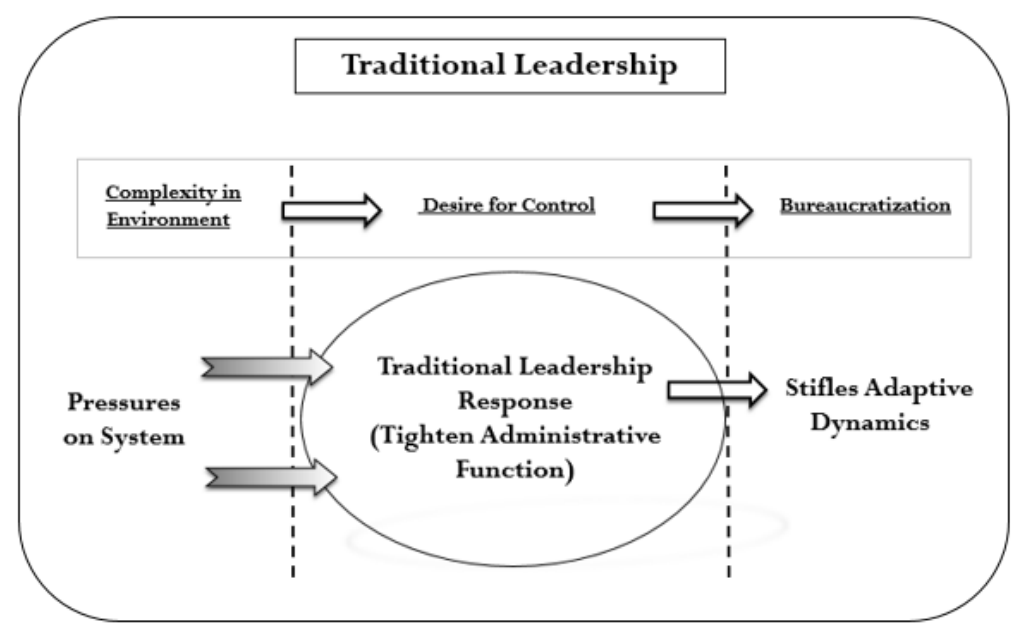

Adapted from Uhl-Bien (2006), Adaptive Space: The Key to Leadership in a Complex World. (p. 643)

In view of the arguments stated above, one can conclude that enterprise leaders in complex adaptive system need formal leaders (administrators) who are knowledgeable in modern style of leadership who are able to work with people who are knowledge-driven individuals and are innovative, creative and technologically know how so as to improve organizational efficiency and effectiveness. They should, therefore, be abreast of a complex adaptive system that is required in this knowledge era of management.

\section{Scope of Complexity Leadership Theory}

Administrative Leadership: Administrative leadership plays formal managerial roles (bureaucratic functions) of the organizational members that coordinate the activities of the organization (Baltaci \& Balc1, 2017; Uhl-Bien \& Marion, 2009). Schneider \& Somers (2006) added that leaders have managerial roles to play in the organization including but not limited to creating an organizational vision, planning sources of production, defining 
policies and strategies as well as workflow regulations. The functions of these leaders vary within the hierarchical structure of the organizations. Managers within the formal structure who may be in charge of the strategic planning unit may as well take care of coordination and resource allocation in the organization. They may also be focusing on planning and coordination of activities that bothers on creativity, supplies and organizational structural regulations. This function is far different from those of informal (Uhl-bien \& Marion, 2009; Bowden \& Smits, 2015).

In the words of Jackson (2012), any formal organizational bureaucracy that considers the downward communication to be an effective way of achieving objectives, the top-down structure becomes the main instrument of the organization to achieve its objectives. By this decision making and organizational success is centered on the hierarchical authority. However this may be the case, the complex adaptive leadership theory expects the structure of such managerial leadership without boundaries and should be transparent enough to allow creativity, resonance and organizational learning formulated through adaptive leadership in times of chaos (Conner, 1998). This approach will encourage innovation, creative solution, and deal with the unpredictable competitive environment (Jackson, 2012).

Adaptive Leadership: is an informal leadership structure in organizations that occurs consciously within the organization through interactions of interdependent individuals as they work together to create solutions and provide novel ideas for organizational objectives to be achieved (Lichtenstein \& Plowman, 2009; Heifetz, Grashow \& Linsky, 2009; Uhl-Bien \& Marion, 2009). This adaptive leadership comes to play because there is a tendency of different needs between formal and informal leadership structure as well as different preferences among the organizational members. Due to this, adaptive leadership seeks organizational change in informal interactions and organizational dynamics, which focuses on individuals and groups (Cilliers, 2001). Adaptive leadership has two ways of asymmetrical interactions. There is one which involves preferences such as diversity of information, beliefs, and skills of the members, and the others are from the authority of the organization. Where the interaction is always from the authority, then the 
asymmetry is top down. However, if it focuses on preferences then the asymmetry is dynamic (Cilliers, 2001).

Enabling Leadership: This leadership operates as an intermediary between administrative and adaptive leadership. Enabling leadership works to bring conducive enabling conditions to the complex dynamics of adaptive leadership and further manages the administrative-to-adaptive and also from innovative-to-organization (Uhl-Bien, Marion \& McKelvey, 2007; Uhl-bien \& Marion, 2009).

The roles of enabling leadership can be summed up as below (Lieberman \& Mace, 2009; Baltaci \& Balc1, 2017):

- Enabling leadership brings to bare complex adaptive system dynamics by fostering adaptive leadership and emergence.

- Enabling leadership deals with the task of managing complexity between administrative (formal) and adaptive (informal) leadership.

This aims particularly at managing organizational setting where adaptive leadership is enforced and also makes innovative products available to help adaptive leadership emerge from the formal management system. Entanglement also looks at how administrative and adaptive leadership can work together for the organization to function well. This explains entanglement to mean a dynamic relationship between formal and informal ecosystem in an organization (Thomas, Kaminska \& McKelvey, 2005; UhlBien \& Marion, 2009; Schneider \& Somers, 2006).

\section{Do We Need Complex Adaptive System in SOEs?}

As businesses today strive to be innovative in its management to achieve optimum, SOEs ought to appropriately adapt and use enabling leadership to achieve the best of CAS that fosters adaptive leadership. Catalyzing of the enterprises is the right way to be effective. Networks that are convenient for adaptive leadership to emerge include interactive, minimal independent, and infused tension structure. The tension caused by chaos will be settled by enabling leadership through linking all dynamic networks and reduction in dependency of members for complex survival and introduction of an adaptive 
system that motivates and synchronize interactive dynamics in the enterprise (Uhl-Bien \& Arena, 2017).

Interaction: adequate network conditions are caused by interaction. Interaction brings about linkages among network across the follow of information. Enabling leaders may not be in the position to define the requirement for sufficient communication network in the SOEs or put up a system of connection that is most appropriate for SOEs complicated networking structure. These networks operate automatically within the enterprise. It is self-organizing a dynamic structure that creates a system of networking that can evolve. At the organizational level, enabling leaders can offer interaction through several strategies as working environment, the architecture of employees and work groups selected by workers, emails, and administrative work schedules by management and office rules structuring (Jaques, 1989; Cilliers, 2001; Uhl-Bien, Marion \& McKelvey, 2007).

Interaction in SOEs as the case may be should not be just for elements in organizational management or workgroups but also in the whole ecosystem of the enterprise who can improve the structures. The enterprise may decide wholly to create steps to improve on the productive activities via movement of materials, human resources, capital and information for subsequent production, either from other related organisations or exchange materials and information from other enterprises for production. Sometimes it could be transfer of knowledge and information and technology with related organisations within or without the same spectrum. This will significantly reduce chaos and improve efficiency and sustainability. This leadership may be able to manage any pressure that environmental dynamics and enterprise may have over a complex adaptive system. This may improve the leadership skills that will extend organizational capacity to get raw material, human resources, and information that will help resonate change of environment to enable the transfer of information which includes a creative dynamic system. Here, environmental dynamics caused by the complex adaptive system will favor management through enabling leadership. This will resonate environmental changes and efficiency, which is a requirement for enabling leadership structure (Bradbury \& Lichtenstein, 2000). 
Those agents in an adaptive system can perform the role of enabling leadership that will enhance interactive contribution. This will open up individuals within the enterprise to increase their interactions and share their information with the sectors within the organization. Through that, productivity will be improved because resources become easily accessible (Boal \& Schlultz, 2007). Besides, members in the agents can involve themselves in the environmental issues by contributing to the information flow of the enterprise by learning the organizational processes to gain insight to be able to interact with others in perspective that enhance organizational production capacity. Through this, organizational members learn and become much more creative in their various area of specialization. Their competency and understanding of the organizational operations will also be enhanced through constant interactions among those within and without the enterprise. Organizational and environmental monitoring should be part of the perspectives agents need to understand to be able to appreciate how these forces influence the adaptive dynamic system. Some of the forces are social, political, economic, technological, national, and international (Schneider \& Somers, 2006; Uhl-Bien \& Marion, 2009).

Fostering Interdependency: in managing complexity, one cannot rely on interaction alone in the enterprise. There is the need to have interdependence of the agents in the ecosystem to avoid pressure caused by information dependency and allow dynamic information movements. Potency in interdependence derived from naturally emergent network networks of conflicting constraints. Such conflicts may be occurring due to stifling of information by one agent when another possesses all the needed information. When these restrictions occur, organizational members may be under severe pressure in controlling production activities at some levels, and the network may be elaborated (Burke, 2013). There are several ways to manage conditions at the organizational level that triggers organizational dependency mechanisms (Jaques, 1989). One of the tools is allowing measured autonomy to enable organizational members to deal with chaos without management intervention and intrusion, notwithstanding the likelihood of creating more conflicts (Shalley, C. E., \& Gilson, 2004). One of the duties leaders in SOEs supposed to perform is to help solve organizational issues through proper interventions. In so doing, organizational interdependence is affected. This 
sometimes limits adaptive system mechanisms within the organizations. Members in the enterprise supposed to enjoy all the freedom to express themselves and share ideas on organizational issues, be creative and bring out new ways of solving organizational problems (Serban et al., 2015).

Adaptive Tension: enabling leadership makes it easy to deal with controversies within the organization. This is possible through leadership strategies gained by the adoption of CLT, resonance, and knowledge accumulation through interaction. The internal tension comes about because of differences among organizational members in the area of skills levels, experience, preferences, and outlooks (McKelvey, 2007). In the case of dependencies, these differences pressurize organizational members to themselves but at the strategic levels these differences are managed to bring diversity and respect among members who intend creates enabling environment for sharing of varying ideas to promote harmony and tolerance in finding solutions to organizational problems (Heifetz, Grashow \& Linsky, 2009; Waldman \& Bowen, 2016). This is the work of enabling leadership, which, in addition to creating tension, also causes environmental elements to create external tension. Leaders at the top of the enterprise structure may create external tension with pressures and managerial challenges by internal practices such as distributing resources to support creative ideas and creating demand for organizational products. Enabling leadership perception of tension in the organisation is a requirement for emergence which in turn supports knowledge transfer and creative ideas. This idea creation and evenly distributed resources is a requirement that can influence emergence in the organisational network dynamics (Smits \& Bowden, 2015). At the individual levels within the enterprise, tension can be dealt with by enabling leaders by indulging in fruitful discussions and interactions that will allow individuals to interact to find solutions to problems and develop new ideas through adaptive system dynamics. This will bring to fore the differences between task conflicts and interpersonal conflict and how to reduce it to improve problem solving capabilities in the organisation (Uhl-Bien, Marion \& McKelvey, 2007). 


\section{Discussion}

The study seeks to ignite a debate within the scholarship and leadership practitioner's fraternity the need to introduce complexity leadership into SOEs to reduce the heroic power and authority of the individual administrative leaders who are imposing on the leadership positions by the political actors. There is the need to move away from the dependency of a few leaders who are seen as super-heroes and possess all the qualities needed to achieve organizational success. Application of complexity leadership theory in SOEs does not exist in scholarly literature and the private sector environment, it is at its infancy stage (Tourish, 2018). This may be because practitioners have not seen the need to have a paradigm shift from the status quo. The instability in the world's economy, coupled with the importance of SOEs to Ghana's emerging economy has necessitated the need to introduce CLT to enhance intrapreneurial skills in these entities. This is because CLT expresses a positivist approach to social science (Maguire, 2011) as the focus is on the interactive nature of the agents in the organization (Tourish, 2018).

Marion \& Uhl-Bien (2011) posit that complex problems in organizations and their subsystems need to be tackled with complex responses and that complexity leadership approach propose strategies that leaders can adapt to solve these problems. Lichtenstien \& Plowman (2009) further reiterate that complexity leaders attempt to minimize chaos and bring orderliness into the organization and its subsystems. It is through this that organizational harmony and commitment emerge which in turn breeds effective performance. Therefore, complexity leadership is seen as a means of leaders encourage experimentation, establish routines, create a proper chain of responsibility, encourage learning culture, and recognize accountability among the agents within the organization (Hazy \& Uhl-Bien, 2013). If we work in the organization, then it makes sense to see leaders and employees interacting to achieve organizational objectives (Tourish, 2018). Consistent with this shift in our thinking, leaders in SOEs cannot depict as a force that stands alone from complex systems and exerts influence to achieve positive results. Given this, leaders are encouraged to open up for interactions with the informal groups to bring emergence to help energize collective action that is inspirational 
(Plowman et al. 2007). This is because CAS as a social network allows employees to interact and interrelate with each other to create collaboration and shared goals and perspectives. CAS has been seen through research to be flexible hierarchical structure connected through multiple ties and interactive networks of those introduced to the social system.

Applying complex leadership theory in SOEs will help address the gap in understanding regarding the formal and informal workings in the organization and the relationship with the administrative control system of traditional bureaucracy by giving a perspective of organizational leadership that recognizes the link between formal and informal dynamics in organizations (Smith \& Graetz, 2006). Besides, complex systems have evolved from the social system theory because of its ability to display resonance, learning, and creative thinking. SOEs surely needs a leadership model that is different from the bureaucratic model. This model in the complex adaptive system has behavioral and knowledge pattern that is new in terms of product and service development because this pattern combines technology and bureaucratic authority to address challenges that may be encountered because it is interactive and dynamic which can stimulate organizational change.

Leaders in SOEs need to position and enable organizations for adaptability in these times of increasingly dynamic and demanding business circles (UhlBien \& Arena, 2018). It is through this that a more positive outcome will flow into the organizations and attract qualified human capital to improve economic growth.

\section{Conclusion}

SOEs continue to remain one of the critical sources of employment and provision of public services in the developing countries. However, bureaucratic leadership style being practiced coupled with unclear mandates of employees, has affected its efficiency over the years. To improve performance, the boundaries of leadership should be eliminated so that leadership may not be used to a suppressive tool, but to collaborate to achieve goals. 
By so doing, well-trained professionals who understand the complex system and how to adapt in times of chaos should be allowed to hold the fort but not political appointees as the situation is today. The existence of multiple leaders in the organization affects its ability to use the structures to gain the success efficiently it wants to, and this pluralized leadership influence the networking relationship that connects people (Denis et al., 2012). This is because they exert influence through the structures formally and informally in complex organizations. The competitive business environment we find ourselves today where the market is fluctuating day-by-day, very unpredictable and chaotic requires a complex adaptive system. The pace of change confronting organizations today have added complexity to the organizational landscape and now calls for more flexible and adaptive leadership.

Adaptive leaders can work more effectively in the unstable global business environment (Rowe \& Guerrero, 2011) and are also able to adopt a proactive approach in order to keep abreast of the increasing stakeholder pressures in the enterprises. Leaders work together with their followers to realize the short and long-term plans of the organization and to achieve specific objectives. An organization does not operate in a vacuum; it is influenced by both internal and external stakeholders (Bryman, 2011). In this regard, the citizens are the stakeholders as state-owned enterprises supposed to perform to better their lives. However, inadequate applicability of traditional leadership models has indicated the need to develop new leadership models to solve complex organizational challenges (Chhokar, Brodbeck \& House, 2012; Harley, Metcalf \& Irwin, 2014; Lichtenstein, Uhl-Bien, Marion, Seers, \& Orton, 2006; Western, 2013).

In conclusion, complexity leadership theory is a theory that taps complex adaptive system leadership behavior in bureaucratic structures. These behaviors are suppressed to a large extent in bureaucratic organizations such as SOEs. The SOEs are supposed to seek to enhance innovation, adaptability, and creative thinking. Hence complexity leadership approach seeks to combine these dynamics to the bureaucratic hierarchies in order to explain the way informal organizational dynamics function correctly and also to describe 
how these valuable adaptive functions can be promoted to better the operations of SOEs in Ghana. Even though Ghana is aggressively striving to industrialized, the industrial age approach of bureaucracy where workers follow the vision of the leader and top-to-bottom control by the leader (Zaccaro \& Klimoski, 2001) cannot be accepted but instead paradigm shift for the complex adaptive system. It is through this that Ghana can meet the requirement of leadership in the 21 st century to manage ever needed stateowned enterprises in a developing country like Ghana.

\section{References}

Abbas, W. \& Asgar, I. (2010). The Role of Leadership in Organizational Change: Relating the Successful Organizational Change to Visionary and Innovative Leadership. Unpublish Master's Thesis. University of Gavle.

Abdullah, A. A., Islam R. \& Al-Homayan, A.M. (2013). The Effect of Leadership Style on Security Guards. Performance : A Case Study on Riyadh Military Hospital in Saudi Arabia, Advances in Envioronmental Biology, 7(9), pp. 2633-2641.

Adams, T. M., \& Stewart, L. D. (2015). Chaos theory and organizational crisis: A theoretical analysis of the challenges faced by the New Orleans Police Department during Hurricane Katrina, Public Organization Review, 15(3), p. 415-431. doi: 10.1007/s11115-0140284-9.

Armandi, B., and Jr, E. (1985). Bureaucratic and Personalized Strategies for Efficiency and Organization: An Investigation of Structures and Efficiency in a Set of 104 Profit- Seeking Firms, American Journal of Economics and Sociology, 44(3), pp. 261-277.

Ashby, W. (2013). Design for a brain: The origin of adaptive behavior. New York: Springer Science \& Business Media.

Alcácer, J., Cantwell, J \& Piscitello, L. (2016). Internationalization in the information age: A new era for places, firms, and international business networks?, Journal of International Business Studies, 47, pp. 499-512. doi: 10.1057/jibs.2016.22. 
Baltaci, A. \& Balc1, A. (2017). Complexity Leadership: A Theoretical Perspective,' International Journal of Educational Leadership and Management, 5(1), p. 30. doi: 10.17583/ijelm.2017.2435.

Bass., B. M., (1985). Leadership: Good, better, best. Organisational Dynamics. Available at: http://doi.org/hmr.

Bass, B. M. (1999). Two Decades of Research and Development in Transformational Leadership, European Journal of Work and Organizational Psychology, 8(1), pp. 9-32.

Bass, B. M. (2002). Forecasting organizational leadership: From back (1967) to the future (2034). In B. J. Avolio \& F. J. Yammarino (Eds.), Transformational and charismatic leadership: The road ahead (pp. 375-384). Oxford, UK: JAI/Elsevier

Barnard, C.I. (1938), The Functions of the Executive, Harvard University Press, Cambridge, MA.

Boal, K., \& Schlultz, P. (2007). Storytelling, time, and evolution: The role of strategic leadership in complex adaptive systems, The Leadership Quarterly, 18(4), p. 411-428.

Boisot, M., \& McKelvey, B. (2010). Integrating modernist and postmodernist perspectives on organizations: A complexity science bridge, Academy of Management Review, 35(3), p. 415-433.

Bradbury, H., \& Lichtenstein, B. M. B. (2000). Relationality in organizational research: Exploring the space between., Organization Science, 11(5), p. 551-564.

Bryman, A. (2011). The SAGE handbook of leadership,. (C. Thousand Oaks, Ed.). London: SAGE.

Burke, W. W. (2013). Organization change: Theory and practice. Washington, DC: Sage Publications.

Burpo, F. J. (2006). The great captains of chaos: Developing adaptive leaders, Military Review, 86(1), p. 64.

Byrne, D., \& Callaghan, G. (2013). Complexity theory and the social sciences: The state of the art. New York: Routledge.

Chan, A., \& Chan, E. (2005). Impact of perceived leadership styles on work outcomes: Case of building professionals, Journal of Construction Engineering \& Management, 131(4), p. 413-422.

Chen, J., Wang, L., Huang, M., \& Spencer-Rodgers, J. (2012). Naïve dialectism and Chinese employees' commitment to change, Journal of 
IJELM- International Journal Educational Leadership \& Management, 7(2) 164
Managerial Psychology,
10.1108/02683941211193857.
27(1),
p. $\quad 48-70$.
doi:

Chesbrough, H. W. (2006). The era of open innovation, Managing innovation and change, 127(3), p. 34-41.

Chhokar, J.S., Brodbeck, F.C. \& House, R. (2012). Culture and leadership across the world: The GLOBE book of in-depth studies of 25 societies, London, Routledge.

Cilliers, P. (2001). Boundaries, Hierarchies, and Networks in Complex Systems, International Journal of Innovation Management, 5(2.), p. 135-147.

Cilliers, P. (2005). Complexity, deconstruction and relativism, Theory, Culture \& Society, 22(5), p. 255-267. doi: 10.1177/0263276405058052.

Conner, D. R. (1998). Leading at the Edge Chaos. New York, NY: John Wiley \& Sons.

Denis, J. -L., Langley, A., \& Sergi, V. (2012). Leadership in the plural, The Academy of Management Annals, 6, p. 211-283. doi: 10.1080/19416520.2012.667612.

Drucker, P., (2012). Managing in the next society. Oxford: Routledge.

Edmonstone, J. (2016). Complex adaptive leadership: embracing paradox and uncertainty, Action Learning: Research and Practice, 13(1), p. 87-89. doi: 10.1080/14767333.2015.1130353.

Fidan, T., \& Oztürk, I. (2015). The relationship of the creativity of public and private school teachers to their intrinsic motivation and the school climate for innovation, Procedia-Social and Behavioral Sciences, 195, p. 905-914. doi: 10.1016/j.sbspro.2015.06.370.

Hazy, J., \& Uhl-Bien, M. (2013). Towards operationalizing complexity leadership: How generative, administrative, and community-building leadership practices enact organizational outcomes — Leadership, 11, 79-104.

Harley, C, Metcalf, L \& Irwin, J. (2014). 'An exploratory study in community perspectives of sustainability leadership in the Murray Darling Basin , Journal of Business Ethics, 124(3), 413-433.

Heifetz, R., Grashow, A., \& Linsky, M. (2009). The practice of adaptive leadership. Boston, MA: Harvard Business School Publishing. 
Hijazi, S., Kasim, A. L., \& Daud, Y. (2017). Leadership Styles and Their Relationship with the Private University Employees' Job Satisfaction in United Arab Emirates. Journal of Public Administration and Governance, 6(4), 110-124.

Hsu, C., Marsh, R., and Mannari, H. (1983). An Examination of the Determinants of Organizational Structure, American Journal of Sociology, 88(5), pp. 975-996.

Jackson, E. (2012). The Contribution of a change in leadership philosophy in a public body in Scotland. Unpublished MBA Dissertation. The University of Stirling.

Jain, P. K., Gupta, S., \& Yadav, S. S. (2014). Public sector enterprises in India. New Delhi, India: Springer.

Jaques, E. (1989). Requisite organization. Arlington, VA: Cason Hall.

Javadin, S., (2007). Principles of Organisation and Management. Negahe: Negahe Danesh Publications.

Jermier, J. M. (1998). Introduction: Critical perspectives on organizational control, Administrative Science Quarterly, 43(2), p. 235-256.

Jesson, J.K., Matheson, L., \& Lacey, F. M. (2011). Doing Your Literature Review. Traditional and Systematic Techniques (3ed ed.). London: SAGE Publications Ltd,

Jones, G. R. (2000). Organizational theory. (3rd ed.). MA: Addison-Wesley, Reading,

Lewin, A., (1952). Group decision and social change in G. E. S. New York: Holt.

Lichtenstein, B. B., and Plowman, D. A. (2009). The leadership of emergence: A complex systems leadership theory of emergence at successive organizational levels, Leadership Quarterly, 20(4), pp. 617-630. doi: 10.1016/j.leaqua.2009.04.006.

Lieberman, A., \& Pointer Mace, D. H. (2009). The role of "accomplished teachers" in professional learning communities: uncovering practice and enabling leadership, Teachers and Teaching: theory and practice, 15(4), p. 459-470.

Loughead, T., Hardy, J., \& Eys, M. (2006). The nature of athlete leadership, Journal of Sport Behavior, 29(2), p. 142-158. 
Maguire, S. (2011). Constructing and appreciating complexity. In P. Allen, S. Maguire, \& B. McKelvey (Eds.), The Sage handbook of complexity and management (pp. 79-92). London: SAGE Publications.

Marion R. \& Uhl-Bien, M. (2001). Leadership in complex organizations, The Leadership Quarterly, 12, p. 389-418.

Marion, R., \& Uhl-Bien, M., (2011). Implications of complexity science for the study of leadership. In P. Allen, S. Maguire, \& B. McKelvey (Eds.), The Sage handbook of complexity and management (pp. 385-399). London: SAGE Publications.

Marion, R. (1999). The edge of organization: Chaos and complexity theories of formal social systems. Oxford: Sage Publications.

McKelvey, B. (2001). Energizing order-creating networks of distributed intelligence, International Journal of Innovation Management, 5, p. 181-212.

Miles, R. E. Snow, C.C. Matthews, J.A., and Miles, G. (1999). Cellularnetwork organizations. In: W. E. Edited by twenty-first-century economics. New York: Macmillan.

Millett, J. D. (1967). Enterprise-Operations and Administration: Some Notes on a Systematic Theory of Organized Endeavor, Public Administration Review, 27(5), pp. 421-428.

Mullins, L. J. (1999). Management and Organisational Behaviour. 5th edn. London: Financial Times/Prentice Hall.

Nonaka, I. \& Nishiguchi, T. (2001). Introduction: Knowledge emergence. Oxford: Oxford University Press.

Northouse, P. G. (2015). Leadership: Theory and practice. New York: Sage.

Odainkey, H. N., \& Simpson, N. Y. (2012). Ensuring accountability in stateowned enterprises (SOEs): Examining the role of annual reports a middle-income country's perspective, Journal of Institute of Public Enterprises, 36, pp. 1-2.

Painter-Morland, M. (2008). Systemic leadership and the emergence of ethical responsiveness, Journal of Business Ethics, 82(2), p. 509-524. doi: 10.1007/s10551-008-9900-3.

Pescosolido, A. T. (2001). Informal leaders and the development of group efficacy, Small Group Research, 32(1), p. 74. 
Plowman, D., Solansky, S., Beck, T., Baker, L., Kulkarni, M., \& Travis, D. (2007). The role of leadership in emergent, self-organization. Leadership Quarterly, 18, 341-356.

Pratuckchai, W., \& Patanapongse, W. (2012). The study of management control systems in state-owned enterprises: A proposed conceptual framework, International Journal of Organizational Innovation, 5, p. $83-115$.

Rogers, M. (2017). Bureaucratic structures and organizational performance: A comparative study of Kampala capital city authority and national planning authority, Journal of Public Administration and Policy Research, 9(1), pp. 1-16. doi: 10.5897/JPAPR2016.0377.

Rowe, W. G. \& Guerrero, L. (2011). Cases in leadership. Los Angeles: Sage Publications.

Schneider, M. (2002). A stakeholder model of organizational leadership, Organization Science, 13(2), p. 209-220.

Schneider, M. and Somers, M. (2006). Organizations as complex adaptive systems: Implications of Complexity Theory for leadership research, Leadership Quarterly, 17(4), pp. 351-365. doi: 10.1016/j.leaqua.2006.04.006.

Schreiber, C. and Carley, K. M. (2005). Ineffective organizational practices at NASA: A dynamic network analysis. Carnegie Mellon University.

Selznick, P. (1948). Foundations of the Theory of Organization.', American sociological review, 13, p. 25-35.

Serban, A., Yammarino, F. J., Dionne, S. D., Kahai, S. S., Hao, C., McHugh, K. A., Sotak, K. L., Mushore, A. B.R., Friedrich, T. L. \& Peterson, D. R. (2015). Leadership emergence in face-to-face and virtual teams: A multi-level model with agent-based simulations, quasi-experimental and experimental tests, Leadership Quarterly, 26(3), pp. 402-418. doi: 10.1016/j.leaqua.2015.02.006.

Shalley, C. E., \& Gilson, L. L. (2004). What leaders need to know: A review of social and contextual factors that can foster or hinder creativity, The Leadership Quarterly, 15(1), p. 33-53.

Shin, D. \& Strausz R (2013). Hierarchical Structures and Dynamic Incentives. Retrieved from http://faculty.arts.ubc.ca/sseverinov/ShinStrausz.pdf. 
Smith, P. S., Hayes, M. L. and Lyons, K. M. (2017). The ecology of instructional teacher leadership' The Journal of Mathematical Behavior, 46, pp. 267-288. doi: 10.1016/J.JMATHB.2016.12.005.

Smits, S. J. \& Bowden, D. E. (2015). A Perspective on Leading and Managing Organizational Change, Economics and Business Review, 1(2), p. 321. doi: 10.18559/ebr.2015.2.1.

Tanlamai, U., \& Juta, P. (2011). Performance assessment in Thai state-owned enterprises, Journal of American Academy of Business 17, p. 223-231. Available at: //www.jaabc.com/journal.htm.

Thomas, C., Kaminska Labbé, R., \& McKelvey, B. (2005). Managing the $\mathrm{MNC}$ and exploitation/exploration dilemma: From static balance to dynamic oscillation. In G. Szulanski, Y. Doz \& J. Porac (Eds.), Advances in Strategic Management: Expanding perspective on the strategic process, Vol. 22 (pp. 213-250), Amsterdam, NL: Elsevier.

Thomas, A. (2012). Governance at South African state-owned enterprises:

What do annual reports and the print media tell us?, Social

Responsibility Journal, 8, p. 448-470. doi:

10.1108/17471111211272057.

Tourish, D. (2018). Is Complexity Leadership Theory Complex Enough? A critical appraisal, some modifications and suggestions for further research, Organization Studies, p 1-20, doi: .org/10.1177/0170840618789207.

Tranfield, D., Denyer, D., \& Smart, P. (2003). Towards a methodology for developing evidence-informed management knowledge by means of a systematic review. British Journal of Management, 14, 207-222.

Tsamenyi, M., Onumah, J., \& Tetteh-Kumah, E. (2010). Post-privatization performance and organizational changes: Case studies from Ghana, Critical Perspective on Accounting, 21, p. 428-442. doi: 10.1016/j.cpa.2008.01.002.

Uhl-Bien, M. \& Arena, M. (2017). Complexity leadership: Enabling people and organizations for adaptability, Organizational Dynamics. Pergamon, 46(1), pp. 9-20. doi: 10.1016/J.ORGDYN.2016.12.001.

Uhl-Bien, M., \& Arena, M. (2018). Leadership for organizational adaptability: A theoretical synthesis and integrative framework. Leadership Quarterly. doi: .org/10.1016/j.leaqua.2017.12.009. 
Uhl-Bien, M. \& Marion, R. (2009). Complexity leadership in bureaucratic forms of organizing: A meso model, Leadership Quarterly, 20(4), pp. 631-650. doi: 10.1016/j.leaqua.2009.04.007.

Uhl-Bien, M., Marion, R. \& McKelvey, B. (2007). Complexity Leadership Theory: Shifting leadership from the industrial age to the knowledge er, Leadership Quarterly, 18(4), pp. 298-318. doi: 10.1016/j.leaqua.2007.04.002.

Van Vugt, M. (2006). Evolutionary Origins of Leadership and Fellowship, Personality and Social Psychology Review, 10, pp. 354-371.

Waldman, D. A., \& Bowen, D. E. (2016). Learning to be a paradox-savvy leader, Academy of Management Perspectives, 30(3), p. 316-327.

Weber, M., (1946). Bureaucracy. From Max Weber: Essays in sociology. University New York: Oxford Univ.

Western, S., (2013). Leadership: A Critical Text. Thousand Oaks, CA: Sage.

Wright, Bradley E., \& S. K. P. (2008). What makes mission matter? Mission valence, public service motivation, and human resource outcomes, 9th National Public Management Research Conference, Tucson, AZ, August 8-13, 2008.

Wriston, M. (1980). In Defense of Bureaucracy, Public Administration Review, 40(2), pp. 179-183.

Yukl, G. A., \& Becker, W. S. (2006). Effective empowerment in organizations, Organizational Management Journal, 3(3), pp. 210231.

Zaccaro \& Klimoski (2001). The nature of organizational leadership: An introduction. San Francisco, CA.: Jossey-Bass. 
Francis Donkor is a Ph.D. student at the School of Management and Economics, University of Electronic Science and Technology of China. His research area is leadership and employee performance.

Contact Address: University of Electronic Science and Technology of China,

School of Management and Economics, No. 2006, Xiyuan Ave, Hi-Tech Zone, Chengdu 611731, Sichuan China PR. E-mail: lastygh@yahoo.com

Dr. Dongmei Zhou is a Lecturer and Ph.D. research supervisor at the School of Management and Economics, University of Electronic Science and Technology of China. She is an Associate Professor and her research area is Entrepreneurship and Small Business Management. Contact Address: University of Electronic Science and Technology of China, School of Management and Economics, No. 2006, Xiyuan Ave, Hi-Tech Zone, Chengdu 611731, Sichuan China PR. E-mail: $536890 @ q q . c o m$ 